tuberculous, and Case IV luetic. In each case regardless of the aetiology, the primary factor was vascular disease, and in each, the course and ultimate outcome were the same.

We are indelsted to Prof. Dr. Meller for his permission to publish these cases and to Dozent Dr. Urbanek for his helpful co-operation.

\title{
BIBLIOGRAPHY
}

1. Leber.-v. Graefe-Saemisch. H. d. ges. Augenheilk., Vol. VII, ii, p. 127.

2. Marple.-Contribution to the Pathology of Vascular Growth into the Vitreous. Trans. Atner. Ophthal. Soc., Vol. IX, p. 254.

\section{LEAD POISONING IN THE FIRST CENTURY}

BY

W. J. Rutherfurd, M.C., M.D.Glasg.

ONE of Martial's Epigrams ${ }^{1}$ suggests the possibility that we have an allusion to a contemporary case of lead poisoning with optic neuritis. ${ }^{2}$ The poet, a debauched and scurrilous Spaniard from Aragon, lived in the days of Nero and Domitian and died somewhere near the year 104 A.D. when over 60 years of age, so the case in question can be roughly dated as occurring in the first century of our era. The epigram is to the effect that a chronic soaker of the name of Phryx had lost the sight of one eye, and was going blind in the other as well. His doctor Heras warned him that the effect of continuing his drinking would be total blindness; at which the patient laughed defiantly and, saying "Good bye" to his remaining eye, ordered cup after cup of his forbidden tipple. "Do you ask the result? While Phryx drank wine his eye drank poison."

The two ingredients of spirituous and other liquors capable of giving rise to optic neuritis are methyl alcohol (or its concomitant impurities) and lead. Methyl alcohol is a dope whose presence in potable liquors is the result of ignorant sophistication with an industrial spirit; lead was a common ingredient of wines and cyders into comparatively recent times, and in lead poisoning there is a substantial danger of optic neuritis and atrophy. Wines and cyder which contain acids quickly become contaminated in contact with lead. It was the frequency of colic in certain of the cyder districts of Devonshire which gave the name of Devonshire colic, as the frequency of it in Poitou gave the name colica Pictonum. ${ }^{3}$ In another of his Epigrams ${ }^{4}$ Martial quite definitely alludes to the presence of lead as a contamination in wine, the special variety indicated by him being new (and so probably crude and highly acid) Sabine wine. Alcohol itself may lead to visual hallucinations, such 
as occur in delirium tremens, but that is quite a different affair from loss of vision.

In these Epigrams Martial alluded by name to quite a number of the contemporary physicians in Rome, some of them evidently being Greeks ${ }^{5}$ (probably vastly superior in professional knowledge and skill to the native product), and two at least being professional failures $^{6.7}$, at whom Martial, as was his way, took the opportunity to fling brutal taunts. Alcon ${ }^{8,9}$ Baccara, a Greek, ${ }^{5}$ Carus, ${ }^{10}$ Cascellius, a dentist, ${ }^{11}$ Dasius, ${ }^{8}$ Diaulus, a one-time chirurgus, ${ }^{6}$ Eros, a beautyspecialist, ${ }^{11}$ though cosmetic operations seem also to have been undertaken by the barbers, ${ }^{12}$ Fannius, a throat-specialist, ${ }^{11}$ Heras, ${ }^{13}$ Hermes, a herniotomist, ${ }^{11}$ Hermocrates, ${ }^{14}$ Herodes, ${ }^{15}$ Hippocrates, ${ }^{16}$ Hyginus, an eye specialist, ${ }^{17}$ _another oculist (ophthalmicus) is pilloried, but not named, ${ }^{18}$-Paccius, ${ }^{19}$ Symmachus, ${ }^{20}$ Sota, ${ }^{22}$ are professional names appearing in his verses; and there may be more, as I do not pretend to have made anything like an exhaustive search for them. In one place ${ }^{21}$ he alluded to the medicae, or women practitioners, but without giving their names. It is unnecessary to remark that there were very many more doctors in Rome than ever happened to obtain the not very enviable distinction of being alluded to by Martial, who was a man of the type that would have found itself sadly at a loss in any country in which there happened to be a law of literary libel. Galen, for instance, gives Andromachus as the name of Nero's physician; Thessalus of Tralles, flourished and blustered in Rome in the time of Nero-and there can be no doubt that a certain Syrian physician of the name of Luke had been in Rome in these days. Heras, however, is memorable as the physician who, according to this casual reference, correlated visual disability with wine-drinking (or as we might put it, optic neuritis with lead poisoning); and had the courage of his convictions sufficiently to advise removal of the cause of the mischief so as to prevent further progress of the threatened blindness. It was not his fault that the patient, with debauched cynicism, refused to follow the advice he had been given. Another interesting allusion to optic neuritis in the first century is given by Celsus who associated blindness and headache with the presence of meningeal haemorrhage from direct cranial injury (de medicina, VIII. 4) : isque ibi concretus magnos dolores moveat, et oculos quibusdam obcaecet. The treatment he advocated was trephining (l.c.). He also noted the occurrence of epilepsy with ocular palsy and visual defect (VI. 6. 36), a group of symptoms into which can be read the papilloedema or optic neuritis of raised intracranial tension, such as may be found in the presence of a cerebral tumour. Cervical rigidity is mentioned in the same work as a sign of meningitis (VIII. 4).

It may serve to place the foregoing details in their correct perspective if the following historical summary with regard to such 
lead-poisoning from the ingestion of contaminated beverages be read in connexion with it. Sir George Newman, in his recent book of essays under the title of Interpreters of Nature, ${ }^{23}$ reminds us that John Huxham, who was born in 1692 and practised in Plymouth, was, in 1739, the first to describe the Devonshire colic, "though he did not know the cause of it. A similar malady was observed by Cadwaladr in 1745 in the West Indies in drinkers of rum distilled through leaden pipes, and in 1757 by Tronchin, the talented physician of Geneva, in drinkers of lead-sweetened wine. Ten years later this mystery was cleared up by Dr. (afterwards Sir) George Baker . . . His 'Essay concerning the Cause of the Endemical Colic of Devonshire,' showed that the disease was connected with large pieces of lead used in the vats and cyder-presses, and he extracted lead from the cyder itself. His work, though it concerned a small and circumscribed problem, was so logical, accurate, and inductive, that it afforded a new method of investigation into the contamination of food supplies, which has been pursued by innumerable workers ever since. It opened a new chapter in the book of Preventive Medicine."

Vitruvius is said to have described chronic lead poisoning resulting from the action of drinking-water in lead pipes. He was a military engineer in the first century B.C., and dedicated his treatise de Architectura to the Emperor Augustus. The author of the Hippocratic Aphorisms, who may, indeed, have been Hippocrates himself in the 5th century B.C., alluded to a form of colic attended by dry dropsy (a pradoxical condition, which may be intended to cover constipation with tympanites), which may quite possibly be an allusion to plumbism. If so, the allusion is by no means as clearly recognizable as is the foregoing. In Aphorisms IV. 11, we read that "those who suffer from colic with peri-umbilical pains and aching in the loins, unrelieved either by purging or by other means, end up with a dry dropsy."

\section{REFERENCES}

1. Epigg, VI, 78.

2. This diagnosis was not recognized by $\mathbf{H}$. Oppenheimer in his Medical and Allied Topics in Latin Poetry (1928), where he alluded to this Epigram by Martial. (Ibid., pp. 141-2, 294-5.)

3. Osler. Principles and Practice of Medicine, ed. 6, 1906, p. 375.

4. plumbea vina, X, 49.

Is it possible, though, that he merely meant to belittle it as a dull and heavy liquor, and spoke metaphorically?

5. Epigg., XI, 74. 6. Ibid., I, 30, 47. 7. Ibid., VIII, 74. 8. Ibid., VI, 70. 9. Ibid., XI, 84. 10. Ibid., X, 77. 11. Ibid., X, 56. 12. Ibid., VI. 64, for Cinnamus; described as a barber in VII, 64. 13. lbid., VI, 78.

14. Ibid., VI, 53. 15. Ibid., IX, 96. 16. Ibid., IX, 94. 17. Ibid., X, 56.

18. Ibid., VIII, 74. 19. Ibid., XIV, 78. 20. Ibid., V, 9, and VI, 70. 21. Ibid., XI, 71. 22. Ibid.. IV, 9.

23. Newman. Interpreters of Nature, 1927, pp. 131-2. 
Front view of opacity with bifurcation of hyaloid artery into vessels carrying blood. These vessels pass along the back of the lens to the posterior surface of the iris. Fine grey strands (obliterated vessels) are to be seen with diffuse beam of slit-lamp. See FIG. 2. 


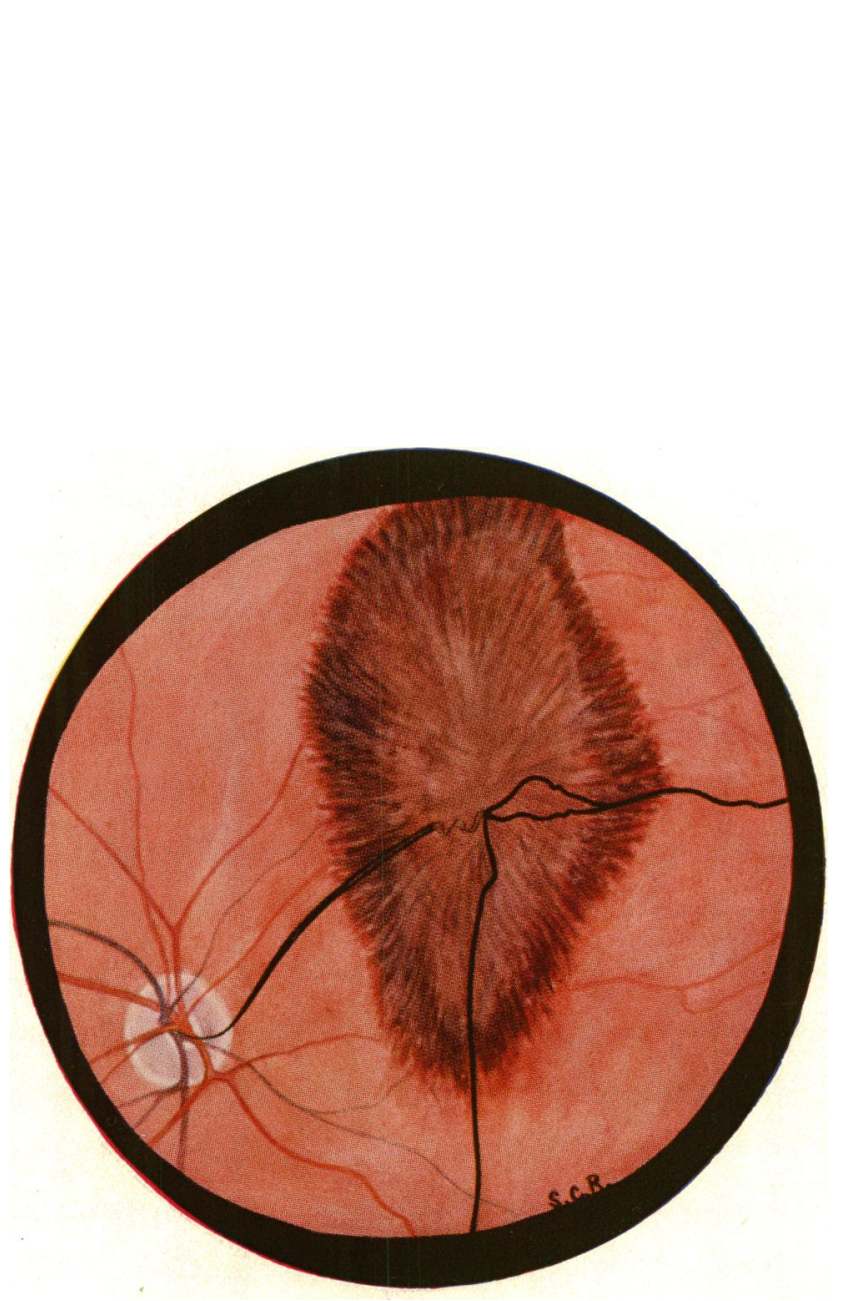

Fig 3.-Ophthalmoscopic Appearance.

The hyaloid artery leaving the disc to opacity at back of lens. The column is of even bore, and as it approaches the lens two curls are seen at, and in the opacity. 